\title{
Molecular epidemiology of vancomycin-resistant Enterococcus faecium clinical isolates in a tertiary care hospital in southern Thailand: a retrospective study
}

\author{
Phanvasri Saengsuwan ${ }^{\text {Corresp., } 1}{ }^{1}$, Kamonnut Singkhamanan ${ }^{1}$, Siribhorn Madla ${ }^{2}$, Natnicha Ingviya ${ }^{3}$, Chonticha \\ Romyasamit $^{4}$ \\ ${ }^{1}$ Department of Biomedical Sciences and Biomedical Engineering, Faculty of Medicine., Prince of Songkla University, Hatyai, Songkhla, Thailand \\ 2 School of Pharmacy, Walailak University, Thasala, Nakhon Si Thammarat, Thailand \\ 3 Department of Pathology, Faculty of Medicine, Prince of Songkla University, Hatyai, Songkhla, Thailand \\ 4 School of Allied Health Sciences, Walailak University, Thasala, Nakhon Si Thammarat, Thailand \\ Corresponding Author: Phanvasri Saengsuwan \\ Email address: sphanvas@medicine.psu.ac.th
}

Objective. Vancomycin-resistant enterococci are nosocomial pathogens that are responsible for commonly causing healthcare-associated infections, and they exhibit increased resistance to many antimicrobials, particularly to vancomycin. The epidemiological data available on vancomycin-resistant enterococci (VRE) in Thailand are inadequate. Methods. Using enterobacterial repetitive intergenic consensus-polymerase chain reaction (ERIC-PCR), this study investigated genes that encode antimicrobial resistance and genetic relatedness to further understand VRE prevalence. Ninety VRE isolates were collected between 2011 and 2019 from a tertiary care hospital in southern Thailand. Antimicrobial susceptibility was determined using the disk diffusion method and E-test methods. Multiplex PCR was performed to detect the van gene and virulence genes.Results. The study showed a high prevalence of diverse multidrug-resistant VRE strains. The prevalence of VRE infection was the highest in 2014 (28 isolates, 39.4\%). VRE were mostly found in the urogenital tract (26 isolates, $28.9 \%$ ), followed by the digestive tract $(20 \%)$, body fluid, i.e., pancreatic cyst fluid, peritoneal dialysis fluid, Jackson-Pratt (JP) drain (20\%), and blood specimens (10\%). Patients in medical and surgical wards had 71.1\% multi-drug-resistant and $28.9 \%$ extensively drug-resistant (XDR) VRE strains, respectively. The most prevalent antibiotic resistance was to ampicillin (74.4\%). Susceptibility to gentamicin and meropenem were similar (7\% and $10 \%$, respectively). Four isolates (4.4\%) were resistant to colistin. Only vanA was detected among the strains. The virulence gene test showed that the detection rates of enterococcal surface protein (esp) and hyaluronidase ( $h y l)$ genes were $91.1 \%$ and $5.6 \%$, respectively. According to ERIC-PCR analysis, 51 of 90 strains had clonality, with a similarity rate of $95 \%$.

Conclusions. We conclude that there is a need to implement infection control practices 
and active surveillance. Molecular techniques can effectively detect antibiotic-resistant genes, which would allow monitoring to control VRE infection in hospitals. 


\section{Molecular Epidemiology of Vancomycin-Resistant}

2 Enterococcus faecium Clinical Isolates in a Tertiary

3 Care Hospital in Southern Thailand: a retrospective

4 study

5

6

7

Phanvasri Saengsuwan ${ }^{1}$, Kamonnut Singkhamanan ${ }^{1}$, Siribhorn Madla², Natnicha Ingviya ${ }^{3}$, Chonticha Romyasamit ${ }^{4}$

${ }^{1}$ Department of Biomedical Sciences and Biomedical Engineering, Faculty of Medicine, Prince of Songkla University, Songkhla, Thailand

${ }^{2}$ School of Pharmacy, Walailak University, Nakhon Si Thammarat, Thailand

${ }^{3}$ Microbiology Unit, Department of Pathology, Faculty of Medicine, Prince of Songkla University, Songkhla, Thailand

${ }^{4}$ School of Allied Health Sciences, Walailak University, Nakhon Si Thammarat, Thailand

Corresponding Author:

Phanvasri Saengsuwan

Department of Biomedical Sciences and Biomedical Engineering, Faculty of Medicine, Prince of Songkla University, Songkhla Province, Thailand

Email address: sphanvas@medicine.psu.ac.th 


\section{Abstract}

Objective. Vancomycin-resistant enterococci are nosocomial pathogens that are responsible for commonly causing healthcare-associated infections, and they exhibit increased resistance to many antimicrobials, particularly to vancomycin. The epidemiological data available on vancomycin-resistant enterococci (VRE) in Thailand are inadequate.

Methods. Using enterobacterial repetitive intergenic consensus-polymerase chain reaction (ERIC-PCR), this study investigated genes that encode antimicrobial resistance and genetic relatedness to further understand VRE prevalence. Ninety VRE isolates were collected between 2011 and 2019 from a tertiary care hospital in southern Thailand. Antimicrobial susceptibility was determined using the disk diffusion method and E-test methods. Multiplex PCR was performed to detect the van gene and virulence genes.

Results. The study showed a high prevalence of diverse multidrug-resistant VRE strains. The prevalence of VRE infection was the highest in 2014 (28 isolates, 39.4\%). VRE were mostly found in the urogenital tract (26 isolates, $28.9 \%$ ), followed by the digestive tract (20\%), body fluid, i.e., pancreatic cyst fluid, peritoneal dialysis fluid, Jackson-Pratt (JP) drain (20\%), and blood specimens (10\%). Patients in medical and surgical wards had $71.1 \%$ multi-drug-resistant and 28.9\% extensively drug-resistant (XDR) VRE strains, respectively. The most prevalent antibiotic resistance was to ampicillin (74.4\%). Susceptibility to gentamicin and meropenem were similar ( $7 \%$ and $10 \%$, respectively). Four isolates (4.4\%) were resistant to colistin. Only vanA was detected among the strains. The virulence gene test showed that the detection rates of enterococcal surface protein (esp) and hyaluronidase (hyl) genes were $91.1 \%$ and $5.6 \%$, respectively. According to ERIC-PCR analysis, 51 of 90 strains had clonality, with a similarity rate of $95 \%$. 
47 Conclusions. We conclude that there is a need to implement infection control practices and

48 active surveillance. Molecular techniques can effectively detect antibiotic-resistant genes, which

49 would allow monitoring to control VRE infection in hospitals. 


\section{Introduction}

52 Vancomycin-resistant enterococci (VRE) are nosocomial pathogens that are responsible for causing a large number of hospital-acquired infections worldwide. These organisms affect the bloodstream, urinary tract, and surgical wounds and cause intra-abdominal and intra-pelvic abscesses (Reyes et al. 2016). Hospitalized patients who have been using certain antibiotics or are on dialysis for a long time are at an increased risk for VRE colonization and infections (Arias et al. 2010; Howden et al. 2013). Enterococci VRE are resistant to commonly used antibiotics, particularly aminoglycoside, ampicillin, vancomycin, and others that affect cell walls (Billington et al. 2014; Puchter et al. 2018).

With the increase in VRE infections among hospitalized patients, the control of VRE prevalence in healthcare units has become a significant concern for public health experts and for our hospital.

Enterococcus faecium and E. faecalis are the most common enterococcal species causing nosocomial infections (Reyes et al. 2016). According to Thailand's National Antimicrobial Resistance Surveillance Center, the prevalence of E. faecium increased from $0.8 \%$ to $9.9 \%$ between 2012 and 2019, but the occurrence of $E$. faecalis has been stable for 10 years $(0.4 \%$ in 2018) (NARST, 2019).

Using molecular techniques, genes associated with enterococcal virulence can be used for identifying, controlling, and preventing E. faecium and E. faecalis transmission, as opposed to using biochemical tests that are expensive and time-consuming (Bhatt et al. 2015b; Fang et al. 2012; Ulu-Kilic et al. 2016). These virulence factors include asa (aggregation substance), gel (gelatinase), cyt (cytolysin), esp (enterococcal surface protein), hyl (hyaluronidase), $c p d$ (sex pheromone determinant), and ebp (endocarditis and biofilm-associated pilus subunit $A)$. 
Esp from E. faecalis contributes to biofilm formation and colonization (Pillay et al. 2018), and hyl influences nasopharynx and lung inflammation (Jackson et al. 2004). The molecular techniques used for the identification of Enterococcus species are multilocus sequence typing, pulsed-field gel electrophoresis (PFGE) (Nasaj et al. 2016), and enterobacterial repetitive intergenic consensus-polymerase chain reaction (ERIC-PCR), which is a simplified typing method for hospital-based epidemiology (Shahi et al. 2020).

No reports are available on the molecular analysis or epidemiology of E. faecium and E. faecalis, and there are limited data on the possible relationship between the prevalence of virulence. This study investigates the incidence rate and genetic relationship of $E$. faecium and $E$. faecalis. We analyze the prevalence of resistance genes using clinical samples collected from a tertiary care hospital in southern Thailand during an 8-year period.

\section{Materials \& Methods}

\section{Study design and clinical isolates}

This retrospective study was conducted at the Songklanagarind Hospital, a 1,000-bed tertiary care hospital in Songkhla province, southern Thailand. The clinical samples used in this study were acquired from patients between February 2011 and February 2019. Nosocomial enterococci and VRE were identified using conventional biochemical tests at the microbiology laboratory in the hospital by referring to guidelines from the Clinical and Laboratory Standards Institute (CLSI) (CLSI 2019). Ninety VRE isolates were included in this study: 5 isolates (6\%) were recovered in $2011 ; 16(18 \%)$ in 2012; $12(13 \%)$ in 2013; $28(31 \%)$ in 2014; 5 (6\%) in 2015; $5(6 \%)$ in 2016; 3 $(3 \%)$ in 2017; $8(9 \%)$ in 2018; and $8(9 \%)$ in 2019 (Table 1). 


\section{Specimen collection and biochemical identification of enterococci species}

Specimen types included blood, body fluid (e.g., pancreatic cyst fluid, peritoneal dialysis fluid, and Jackson-Pratt (JP) drain), urine, midstream urine, pus, and samples from the pelvic region, rectum, and tissue. Before use in experiments, all VRE isolates were preserved in $20 \%$ glycerol at $-80^{\circ} \mathrm{C}$. Sampling of specimen was granted an exemption from requiring ethics approval by the ethical committee of the Faculty of Medicine, Prince of Songkhla University (REC-60-183-04-8).

\section{Antimicrobial susceptibility tests}

Antimicrobial susceptibility tests were performed using the disk diffusion method according to CLSI guidelines (CLSI 2019). Each disk (Becton Dickinson, Heidelberg, Germany) contained ampicillin (AM, $10 \mu \mathrm{g})$, cefoperazone-sulbactam (sulperazone) (SPZ, 75/30 $\mu \mathrm{g})$, cefotaxime (CTX, $30 \mu \mathrm{g})$, ceftazidime (CAZ, $30 \mu \mathrm{g})$, ceftriaxone (CRO, $30 \mu \mathrm{g})$, ciprofloxacin (CIP, $5 \mu \mathrm{g})$, colistin (DA, $10 \mu \mathrm{g}$ ), ertapenem (ETP, $10 \mu \mathrm{g})$, gentamicin (GM, $10 \mu \mathrm{g})$, imipenem (IMP, $10 \mu \mathrm{g})$, meropenem (MEM, $10 \mu \mathrm{g}$ ), norfloxacin (NOR, $10 \mu \mathrm{g}$ ), penicillin (P, $10 \mu \mathrm{g}$ ), tazocin (TZP, 100/10 $\mu \mathrm{g}$ ), and vancomycin (VA, $30 \mu \mathrm{g})$.

Susceptibility testing results were classified as sensitive, intermediate, and resistant according to CLSI breakpoints. Multidrug-resistant (MDR) strains were defined as strains that were resistant to one or more agents in three or more antimicrobial categories (Magiorakos et al. 2012). The minimum inhibitory concentration (MIC) levels for ampicillin-resistant and vancomycinresistant strains are presented as $\mathrm{MIC} \geq 16 \mu \mathrm{g} / \mathrm{mL}$ and $\mathrm{MIC} \geq 8 \mu \mathrm{g} / \mathrm{mL}$, respectively.

\section{Identification of Enterococcus faecium and $E$. faecalis at the species level by multiplex} PCR

The genes encoding D-alanine ligases specific for E. faecium (ddl E. faecium) and E. faecalis (ddl E. faecalis) and 16S rRNA genes ( $r r s$ ) were detected by a modified multiplex PCR technique using 
the primers in Table 2 (Dutka-Malen et al. 1995). The process used was initial denaturation at $95^{\circ} \mathrm{C}$ for $10 \mathrm{~min}$, denaturation at $95^{\circ} \mathrm{C}$ for $45 \mathrm{~s}$, annealing at $54^{\circ} \mathrm{C}$ for $1 \mathrm{~min}$, and extension at $72^{\circ} \mathrm{C}$ for 1 min (35 cycles) (Bhatt et al. 2015a). The PCR products were visualized on 1.0\% agarose gel.

\section{DNA extraction}

Ninety isolates of VRE originating from specimens in a tertiary care teaching hospital (Songkhla, Thailand) were extracted for chromosomal DNA using a GF-1 bacterial DNA extraction kit (Vivantis Technologies Sdn. Bhd., Malaysia) in accordance with the manufacturer's instructions. DNA concentrations were quantified using a spectrophotometer at an absorbance of $260 \mathrm{~nm}$ $\left(A_{260}\right)$. DNA purity was calculated from the ratio of $A_{260}$ and $A_{280}$, and DNA quality was evaluated using agarose gel electrophoresis.

\section{Detection of van genes and virulence genes}

All isolates resistant to vancomycin were subjected to a multiplex PCR analysis to detect vancomycin-resistant and virulence genes using a specific primer as detailed in Table 2 (Bhatt et al. 2015a; Bourgogne et al. 2007; Elsner et al. 2000; Vankerckhoven et al. 2004). PCR amplification was performed via initial denaturation for 3 min at $94^{\circ} \mathrm{C}$; 35 cycles of amplification consisting of $1 \mathrm{~min}$ at $94^{\circ} \mathrm{C}, 1 \mathrm{~min}$ at $54^{\circ} \mathrm{C}$, and $1 \mathrm{~min}$ at $72^{\circ} \mathrm{C}$; and a final extension for 5 min at $72^{\circ} \mathrm{C}$. A 100-bp DNA ladder (GeneDireX, Germany) was used as a molecular-size marker.

ATCC 700221 (for vanA) and E. faecalis ATCC 51299 (for vanB) were used as positive controls. The PCR product was sent for sequencing $\left(1^{\text {st }}\right.$ BASE DNA Sequencing Services, Selangor, Malaysia), and Basic Local Alignment Search Tool search was performed using the National Center for Biotechnology Information database. 


\section{Genotyping by enterobacterial repetitive intergenic consensus (ERIC)-PCR}

An ERIC-PCR typing was performed on enterococci strains using the protocol described by Versalovic et al. (Versalovic et al. 1991) with some modifications. ERIC-1 (ATGTAAGCTCCTGGGGATTCAC) and ERIC-2 (AAGTAAGTGACTGGGGTGAGCG) were the primers. Each PCR reaction $(25 \mu \mathrm{L})$ contained $10 \times$ buffer $(2.5 \mu \mathrm{L}), 0.5 \mathrm{mmol} / \mathrm{L}$ dNTPs $(1 \mu \mathrm{L}), 5$ $\mathrm{U} / \mu \mathrm{L}$ Taq DNA polymerase $(0.2 \mu \mathrm{L}), 100 \mathrm{mmol} / \mathrm{L} \mathrm{MgCl} 2(0.75 \mu \mathrm{L}), 100 \mathrm{~mol} / \mathrm{L}$ primers (each 0.25 $\mu \mathrm{L})$, template genomic DNA $(2 \mu \mathrm{L})$, and distilled water (add to $25 \mu \mathrm{L}$ ). Amplifications were performed using a C1000 Touch Thermal Cycler (Bio-Rad Laboratories) under the following temperature profiles: initial denaturation at $95^{\circ} \mathrm{C}$ for $5 \mathrm{~min} ; 35$ cycles of $1 \mathrm{~min}$ at $95^{\circ} \mathrm{C}, 1 \mathrm{~min}$ at $48^{\circ} \mathrm{C}$, and $1 \mathrm{~min}$ at $72^{\circ} \mathrm{C}$; and a final extension at $72^{\circ} \mathrm{C}$ for $10 \mathrm{~min}$. The ERIC-PCR products were separated by electrophoresis in a $1.0 \%$ agarose gel with ViSafe green gel stain $(0.001 \%$, v/v; Vivantis Technologies Sdn. Bhd., Malaysia) and visualized using the Gel Doc ${ }^{T M} \mathrm{XR}^{+}$system (BioRad Laboratories, Hercules, CA, US). The images were captured in a TIFF file for further analysis. ERIC-PCR patterns were analyzed using BioNumerics 7.0 software (Applied Maths, Sint-Martens-Latem, Belgium). A similarity matrix was estimated using Dice's coefficient, and a dendrogram was created based on the unweighted-pair group method with arithmetic averages.

Enterococci isolates with a similarity coefficient $\geq 85 \%$ were considered as the same genotype (Said \& Abdelmegeed 2019).

\section{Statistical analysis}

Demographic data are presented as percentages (unless otherwise stated) and median values with interquartile ranges (IQR). All statistical analyses were performed using SPSS Statistics version 23 (IBM Corporation, Armonk, New York, US). Qualitative variables were compared using a t-test and Pearson's chi-squared test. A $P$-value $<0.050$ was considered statistically significant. 
177

178

179

180

181

182

183

184

185

186

187

188

189

190

191

192

193

194

195

196

197

198

199

200

\section{Ethical approval}

This study protocol was approved by the Ethics Committee of the Faculty of Medicine, Prince of Songkhla University (Date: August 4, 2017; Approval ID: REC-60-183-04-8).

\section{Results}

\section{Characteristics of the study population and VRE sources}

Of the $90 \mathrm{VRE}$ isolates recovered from patients, 53 (58.9\%) were from females and $37(41.1 \%)$ were from males, for a female-to-male ratio of 3:2. Fifty percent of VRE positive patients were $\geq 65$ years old, and the mean age was 64 years (IQR, 43.5-73; range, 3 months to 90 years). Among these isolates, $42(46.7 \%)$ were obtained from the medical ward; $18(20.0 \%)$ from the surgical ward; and $10(11.1 \%)$ from the intensive care unit. Urine samples had the highest percentage of VRE of $28.9 \%(26)$, followed by those obtained from the rectal area at $20 \%$ (18) and body fluid at $20 \%$ (18). The period of collective sample and source of samples showed statistically significant difference with an antimicrobial pattern $(P<0.05)$, but no significant difference was observed in gender, age groups, and hospital units. The pooled prevalence of VRE infections was $9.6 \%(95 \% \mathrm{Cl}: 3.948-16.052)$. More epidemiological data are presented in Table 3.

\section{Antimicrobial resistance profiles}

Each VRE isolate was tested for susceptibility to different classes of antimicrobials (sterile fluid, such as blood, and nonsterile sources, such as pus and surgical sites). Of the total 90 VRE isolates, 67 (74.4\%) were tested against ampicillin; 57 (63.3\%) against imipenem; 21 (23.3\%) against gentamicin; 10-20 (11.1\%-12.2\%) against tazocin, ceftriaxone, cefotaxime, ceftazidime, 
201

202

cefoperazone-sulbactam, meropenem, penicillin, and vancomycin; and less than $10(<11.1 \%)$, against colistin, norfloxacin, ciprofloxacin, and ertapenem.

On the basis of the diameter of the observed zone of inhibition, the result of antibiotic resistance showed that all the selected VRE isolates were found to be resistant to ampicillin, vancomycin, penicillin, tazocin, norfloxacin, and ciprofloxacin susceptibility. Of the 57 selected VRE isolates, $56(98.2 \%)$ were resistant to imipenem. However, over $50 \%$ of selected VRE isolates exhibited resistance when tested for gentamicin, cefoperazone-sulbactam, ceftazidime, cefotaxime, ceftriaxone, colistin, and ertapenem (Table 4).

The determination of MIC levels for vancomycin to VRE isolates showed that all the strains of VRE were resistant to vancomycin with MIC ranging between $0.25 \mu \mathrm{g} / \mathrm{ml}$ and $256 \mu \mathrm{g} / \mathrm{ml}$. Seventy-three isolates had MIC of $\geqslant 256 \mu \mathrm{g} / \mathrm{ml}$, and seven had MIC of $128 \mu \mathrm{g} / \mathrm{ml}$. One isolate was in the intermediate range with the MIC ranging between $8 \mu \mathrm{g} / \mathrm{ml}$ and $16 \mu \mathrm{g} / \mathrm{ml}$ (Table 5)

\section{Detection of van determinants and virulence factor genes in VRE}

Ninety VRE strains (100\%) harbored the vanA gene, whereas the vanB, vanC, vanD, vane, and vanG genes were not found in any of these isolates. The esp and hyl genes were found in 82 $(91.1 \%)$ and 5 (5.6\%) isolates, respectively. However, gel, cyt, cpd, and ebp genes were absent from all isolates. The amplicons of the VRE isolates and resistance-gene distribution are shown in Figure 1.

\section{ERIC-PCR analysis}

The ERIC-PCR patterns of the 90 VRE isolates are shown in Figure 2. The number of bands in each varied from one to nine, and the ERIC fragment sizes ranged from $100 \mathrm{bp}$ to $1.5 \mathrm{~kb}$. Genomic typification by ERIC-PCR revealed that 51 VRE isolates (56.7\%) were grouped into 14 clusters $(A-N)$ at a similarity level of $95 \%$. The predominant A genotype contained 12 isolates; $B$ genotype, 6 isolates; C-E genotypes, 4 isolates; $\mathrm{F}-\mathrm{H}$ genotypes, 3 isolates; and I-N genotypes, 2 isolates. 
Thirty-nine isolates were uniquely genotyped. MDR and XDR isolates were distributed among all scattered patterns, except for the three genotypes of the XDR pattern (J, L, and N) (Table 6). The heterogeneity among the isolates obtained from urinary tract infections was stronger than those from other infection sites.

\section{Discussion}

Enterococci significantly contribute to nosocomial infections. These infections most often occur in health care settings, particularly in intensive care units (ICU). They can spread by person-toperson contact or from contaminated medical devices (Olawale et al. 2011). Control measures to prevent the spread of enterococci infections are essential. To monitor the spread of enterococci infections at our hospital, samples collected from patients are routinely screened by conventional biochemical tests for nosocomial enterococci (resistant or sensitive to vancomycin). The prevalence of VRE among the nosocomial enterococci isolates in our study was $0.2 \%-4.3 \%$, resulting in an average prevalence of $1.2 \%$.

The prevalence of VRE isolates in our study was relatively low compared with that found in India (7.0\%) (Bhatt et al. 2015b) and in Egypt (6.3\%) (Said \& Abdelmegeed 2019), indicating that risks of VRE infections may be associated with geographic variability. Blanco et al reported in 2017 that relative humidity and geographical location were factors affecting VRE colonization rates in adult patients admitted to ICUs in the United States (Blanco et al. 2017). Increasing humidity resulted in a greater VRE colonization rate, and VRE colonization was lower in southern states. In developing countries, hospitals could inadvertently be increasing the risks of VRE colonization and infections because of the lack of oversight procedures for transferring patients from hospitals with VRE outbreaks (Kang et al. 2014; Resende et al. 2014).

Risk factors for severity of the patient's condition, hemodialysis, and central venous catheter usage and in univariate analysis include male gender, alcohol use, and antibiotics. 
252

Hospitalization in certain units of the hospital and lack of isolation measures are primary factors that affect VRE acquisition (Fossi Djembi et al. 2017). Our study demonstrated similar results after our 90 patients, whose test samples were positive for VRE, were paired with demographic and clinical data from the patient database. Nearly $50 \%$ of VRE carrier patients were $\geq 65$ years old, with a median age of 64 years, and were admitted to the medical ward. In a 2019 study by Mathis et al., older patients had the highest infection during VRE outbreak in 2013-2014 at a teaching hospital in Lyon, France (Mathis et al. 2019).

In addition, positive VRE samples were detected in urine specimens (28.9\%), followed by those obtained from body fluid (20.0\%) and the rectal area (20.0\%). These results were similar to a Brazilian study of VRE infection, where the highest VRE concentrations were isolated from patients with urinary tract infections (Resende et al. 2014). Vancomycin-resistant E. faecalis is a significant cause of nosocomial infections stemming from the urinary tract, surgical wounds, and catheter use and affecting the bladder, prostate, and kidneys (Zalipour et al. 2019).

Because VRE are multidrug-resistant organisms with limited therapeutic alternatives that result in increased morbidity and mortality in patients (Buetti et al. 2019; Zalipour et al. 2019), we examined the 90 VRE isolates in our study for antimicrobial susceptibility. The findings showed resistance to $\beta$-lactam, glycopeptide, and fluoroquinolone antibiotics in most of the tested isolates, with the highest resistance rate to ampicillin (74.4\%) and imipenem (62.2\%).

Enterococci have intrinsic resistance to several classes of antibiotics that inhibit cell wall synthesis, such as $\beta$-lactams and glycopeptides, and they exhibit the ability to acquire new mechanisms of resistance, particularly to penicillin/ampicillin, aminoglycosides (high-level resistance), and glycopeptides (Cetinkaya et al. 2000; Gagetti et al. 2019; Werner et al. 2008). Results also showed susceptibility to meropenem in 10 of 15 tested isolates and 7 of the 21 tested isolates were susceptible to gentamicin. Meropenem and gentamicin are $\beta$-lactam and aminoglycoside antibiotics, respectively, and combinations of meropenem and aminoglycosides could function as alternative therapies for multi- and VRE infections. Similarly, there is evidence 
that $\beta$-lactams in combination with daptomycin reduced bacterial activity (Smith et al. 2015). Moreover, this combination of antibiotic therapy was successful in the treatment of endocarditis/severe MDR enterococcal infection (Antony et al. 1997; El Rafei et al. 2018).

E. faecium and E. faecalis are most frequently detected, and E. durans, E. avium, E. casseliflavus, E. hirae, E. gallinarum, E. raffinosus, and E. muntdii are less commonly detected (Agudelo Higuita \& Huycke 2014; Zaheer et al. 2020). In this study, all the detected VRE isolates were identified as E. faecium, a species rarely found in Songklanagarind Hospital. Other studies have found that vancomycin-resistant genetic elements can transfer between enterococcal species (Murray 1998). Most VRE isolates were MDR, and only six VRE isolates were extensively drug-resistant (XDR). All VRE isolates in this study were vanA E. faecium strains, whereas vanB, $C, D$, and $E$ were not detected, similar to the findings from a 2014 report from Resende et al. (Resende et al. 2014).

Enterococcal virulence that results in pathogenicity is considered a multifactorial process (Comerlato et al. 2013). Virulence factors promoting the emergence of hospital-acquired enterococcal infections have been reported in a number of studies. In our study, VRE strains originally isolated from urine specimen expressed a high frequency of the esp gene (91.1\%), confirming the important role of esp in enterococcal colonization and biofilm formation in urinary tract infections (Comerlato et al. 2013). This finding was comparable to that of other investigators who reported that the incidence levels of esp in E. faecium isolates were $71.5 \%$ in northwest Iran (Sharifi et al. 2012) and 90\% in China (Yang et al. 2015) but rather low in southwest Iran (57.5\%) (Arshadi et al. 2018).

Other virulence factors, hyl, asa, gel, and cyt genes, were also analyzed. The hyl gene was detected in only five (5.6\%) VRE isolates in our study, similar to the findings from Haghi et al. who found the hyl gene in 3 of 79 (3.8\%) VRE isolates in northwest Iran (Haghi et al. 2019). We did not detect the asa, gel, and cyt genes, confirming that esp and hyl are primary virulence factors among clinical strains of vanA E. faecium and play an important role in pathogenesis. 
Molecular techniques for typing bacteria can vary when comparing standardization,

305

cost, reproducibility, discriminatory power, and interpretation. We found that ERIC-PCR is a straightforward procedure for distinguishing organisms that are closely related. This method is less expensive and faster than many other methods, such as PFGE and amplified fragment length polymorphism typing (Borgmann et al. 2007).

The ERIC-PCR results identified 14 clusters among the 51 VRE isolates. The majority of the isolates were clustered in the A genotype, mostly from urine samples, and collected from the medical ward, and these were resistant to ampicillin, gentamicin, and carbapenem, similar to a report from Columbia (Corredor et al. 2019). We identified 39 unique traits of VRE isolates in our study, implying a circulation of these strains in the Songklanagarind Hospital for a period of time prior to the present study. These findings may suggest a hospital epidemiology stemming from the spread of MDR and vancomycin-resistant $E$. faecium with endemic vanA VRE. These bacteria may contribute to antibiotic resistance and virulence through horizontal gene transfer.

\section{Conclusions}

This was the first study conducted in a tertiary care hospital in southern Thailand to show a high prevalence of MDR and XDR-VRE in patients, which could lead to pathogenic effects on public health. The results of this study suggest that overused antibiotics appear to be mediated mainly by the vanA gene, which carries one or two virulence genes that create a high resistance level to vancomycin. However, molecular techniques are highly effective in detecting antibiotic-resistant genes, which would allow monitoring to control VRE infection in hospitals.

\section{Acknowledgments}


328 This study was supported by the government budget of Prince of Songkla University, with a

329 grant number of MED601339S.

330

331 Conflicts of interest

332

333

The authors declare no conflicts of interest.

334 


\section{References}

Agudelo Higuita NI, and Huycke MM. 2014. Enterococcal Disease, Epidemiology, and Implications for Treatment. In: Gilmore MS, Clewell DB, Ike Y, and Shankar N, eds. Enterococci: From Commensals to Leading Causes of Drug Resistant Infection. Boston: Massachusetts Eye and Ear Infirmary.

Antony SJ, Ladner J, Stratton CW, Raudales F, Dummer SJ. 1997. High-level aminoglycosideresistant enterococcus causing endocarditis successfully treated with a combination of ampicillin, imipenem and vancomycin. Scand $J$ Infect Dis 29:628-30. 10.3109/00365549709035908

Arias CA, Contreras GA, and Murray BE. 2010. Management of multidrug-resistant enterococcal infections. Clin Microbiol Infect 16:555-562. doi: 10.1111/j.1469-0691.2010.03214.x.

Arshadi M, Mahmoudi M, Motahar MS, Soltani S, and Pourmand MR. 2018. Virulence determinants and antimicrobial resistance patterns of vancomycin-resistant enterococcus faecium isolated from different sources in southwest Iran. Iran J Public Health 47:264-272.

Bhatt P, Sahni A, Praharaj A, Grover N, Kumar M, Chaudhari C, and Khajuria A. 2015a. Detection of glycopeptide resistance genes in enterococci by multiplex PCR. Med $\mathrm{J}$ Armed Forces India 71:43-47.

Bhatt P, Sahni AK, Praharaj AK, Grover N, Kumar M, Chaudhari CN, and Khajuria A. 2015. Detection of glycopeptide resistance genes in enterococci by multiplex PCR. Med J Armed Forces India 71:43-47. 10.1016/j.mjafi.2014.03.005

Billington EO, Phang SH, Gregson DB, Pitout JD, Ross T, Church DL, Laupland KB, and Parkins MD. 2014. Incidence, risk factors, and outcomes for Enterococcus spp. blood stream infections: a population-based study. Int J Infect Dis 26:76-82. 10.1016/j.ijid.2014.02.012

Blanco N, Perencevich E, Li SS, Morgan DJ, Pineles L, Johnson JK, Robinson G, Anderson DJ, Jacob JT, Maragakis LL, Harris AD, and Program CDCPE. 2017. Effect of meteorological factors and geographic location on methicillin-resistant Staphylococcus aureus and vancomycin-resistant enterococci colonization in the US. PloS one 12:e0178254e0178254. 10.1371/journal.pone.0178254 
Borgmann S, Schulte B, Wolz C, Gruber H, Werner G, Goerke C, Klare I, Beyser K, Heeg P, and Autenrieth IB. 2007. Discrimination between epidemic and non-epidemic glycopeptideresistant E. faecium in a post-outbreak situation. J Hosp Infect 67:49-55. 10.1016/j.jhin.2007.06.002

Bourgogne A, Singh KV, Fox KA, Pflughoeft KJ, Murray BE, and Garsin DA. 2007. EbpR is important for biofilm formation by activating expression of the endocarditis and biofilmassociated pilus operon (ebpABC) of Enterococcus faecalis OG1RF. J Bacteriol 189:6490-6493. 10.1128/JB.00594-07

Buetti N, Wassilew N, Rion V, Senn L, Gardiol C, Widmer A, and Marschall J. 2019. Emergence of vancomycin-resistant enterococci in Switzerland: a nation-wide survey. Antimicrob Resist Infect Control 8:16. 10.1186/s13756-019-0466-x

Cetinkaya Y, Falk P, and Mayhall CG. 2000. Vancomycin-resistant enterococci. Clinical microbiology reviews 13:686-707. 10.1128/cmr.13.4.686-707.2000

Clinical and Laboratory Standards Institute (CLSI). Performance standards for antimicrobial susceptibility testing; Twenty-nineth Informational Supplement M100-S29, Wayne, PA: CLSI; 2019.

Comerlato CB, Resende MCCd, Caierão J, and d'Azevedo PA. 2013. Presence of virulence factors in Enterococcus faecalis and Enterococcus faecium susceptible and resistant to vancomycin. Memorias do Instituto Oswaldo Cruz 108:590-595. 10.1590/s007402762013000500009

Corredor NC, López C, Aguilera PA, Prieto LM, Rodríguez-Leguizamón G, Leal AL, OvalleGuerro MV, Pardo-Oviedo JM, Chica CE, and Patarroyo MA. 2019. An epidemiological and molecular study regarding the spread of vancomycin-resistant Enterococcus faecium in a teaching hospital in Bogotá, Colombia 2016. BMC Infect Dis 19:258-258. 10.1186/s12879-019-3877-7

Dutka-Malen S, Evers S, and Courvalin P. 1995. Detection of glycopeptide resistance genotypes and identification to the species level of clinically relevant enterococci by PCR. J Clin Microbiol 33:24-27.

El Rafei A, DeSimone DC, Narichania AD, Sohail MR, Vikram HR, Li Z, Steckelberg JM, Wilson, WR, and Baddour LM. 2018. Comparison of dual $\beta$-Lactam therapy to penicillin- 
aminoglycoside combination in treatment of Enterococcus faecalis infective endocarditis. J Infect 77:398-404. 10.1016/j.jinf.2018.06.013

Elsner H-A, Sobottka I, Mack D, Laufs R, Claussen M, and Wirth R. 2000. Virulence factors of Enterococcus faecalis and Enterococcus faecium blood culture isolates. Eur $J$ Clin Microbiol Infect Dis 19:39-42.

Fang H, Ohlsson AK, Ullberg M, and Ozenci V. 2012. Evaluation of species-specific PCR, Bruker MS, VITEK MS and the VITEK 2 system for the identification of clinical Enterococcus isolates. Eur J Clin Microbiol Infect Dis 31:3073-3077. 10.1007/s10096-012-1667-x

Fossi Djembi L, Hodille E, Chomat-Jaboulay S, Coudrais S, De Santis N, Gardes S, Mauranne CC, Mourey N, Fredenucci I, and Girard R. 2017. Factors associated with vancomycinresistant Enterococcus acquisition during a large outbreak. J Infect Public Health 10:185190. 10.1016/j.jiph.2016.04.010

Gagetti P, Bonofiglio L, García Gabarrot G, Kaufman S, Mollerach M, Vigliarolo L, von Specht M, Toresani I, and Lopardo HA. 2019. Resistance to $\beta$-lactams in enterococci. Rev Argent Microbiol 51:179-183. https://doi.org/10.1016/j.ram.2018.01.007

Haghi F, Lohrasbi V, and Zeighami H. 2019. High incidence of virulence determinants, aminoglycoside and vancomycin resistance in enterococci isolated from hospitalized patients in Northwest Iran. BMC Infect Dis 19:744-744. 10.1186/s12879-019-4395-3

Howden BP, Holt KE, Lam MMC, Seemann T, Ballard S, Coombs GW, Tong SYC, Grayson ML, Johnson PDR, and Stinear TP. 2013. Genomic insights to control the emergence of vancomycin-resistant Enterococci. mBio 4:e00412-00413. 10.1128/mBio.00412-13

Jackson CR, Fedorka-Cray PJ, and Barrett JB. 2004. Use of a genus- and species-specific multiplex PCR for identification of Enterococci. J Clin Microbiol 42:3558-3565. 10.1128/jcm.42.8.3558-3565.2004

Kang M, Xie Y, He C, Chen ZX, Guo L, Yang Q, Liu JY, Du Y, Ou QS, and Wang LL. 2014. Molecular characteristics of vancomycin-resistant Enterococcus faecium from a tertiary care hospital in Chengdu, China: molecular characteristics of VRE in China. Eur J Clin Microbiol Infect Dis 33:933-939. 10.1007/s10096-013-2029-z

Magiorakos AP, Srinivasan A, Carey RB, Carmeli Y, Falagas ME, Giske CG, Harbarth S, Hindler JF, Kahlmeter G, Olsson-Liljequist B, Paterson DL, Rice LB, Stelling J, Struelens MJ, Vatopoulos A, Weber JT, and Monnet DL. 2012. Multidrug-resistant, extensively drug- 
resistant and pandrug-resistant bacteria: an international expert proposal for interim standard definitions for acquired resistance. Clin Microbiol Infect 18:268-281. https://doi.org/10.1111/j.1469-0691.2011.03570.x

Mathis B, Haïne M, Girard R, and Bonnefoy M. 2019. Risk factors for vancomycin-resistant enterococcus acquisition during a large outbreak in patients aged 65 years and older. BMC Geriatr 19:377-377. 10.1186/s12877-019-1398-2

Murray BE. 1998. Diversity among multidrug-resistant enterococci. Emerg Infect Dis 4:37-47. 10.3201/eid0401.980106

Nasaj M, Mousavi SM, Hosseini SM, and Arabestani MR. 2016. Prevalence of virulence factors and vancomycin-resistant genes among Enterococcus faecalis and E. faecium Isolated from Clinical Specimens. Iran J Public Health 45:806-813.

National Antimicrobial Resistance Surveillance Thailand. Situation of antimicrobial resistance during 2000-2019, 2020. [cited 2020 Oct 09] Available from URL: http:// http://narst.dmsc.moph.go.th/data/AMR\%202000-2019-12M.pdf.

Olawale KO, Fadiora SO, and Taiwo SS. 2011. Prevalence of hospital-acquired enterococci infections in two primary-care hospitals in osogbo, southwestern Nigeria. Afr J Infect Dis 5:40-46. 10.4314/ajid.v5i2.66513

Pillay S, Zishiri OT, and Adeleke MA. 2018. Prevalence of virulence genes in Enterococcus species isolated from companion animals and livestock. Onderstepoort $J$ Vet Res 85:1-8.

Puchter L, Chaberny IF, Schwab F, Vonberg R-P, Bange F-C, and Ebadi E. 2018. Economic burden of nosocomial infections caused by vancomycin-resistant enterococci. Antimicrob Resist Infect Control 7:1. 10.1186/s13756-017-0291-z

Resende M, Caierao J, Prates JG, Narvaez GA, Dias CA, and d'Azevedo PA. 2014. Emergence of vanA vancomycin-resistant Enterococcus faecium in a hospital in Porto Alegre, South Brazil. J Infect Dev Ctries 8:160-167. 10.3855/jidc.4126

Reyes K, Bardossy AC, and Zervos M. 2016. Vancomycin-Resistant Enterococci: Epidemiology, Infection Prevention, and Control. nfect Dis Clin North Am 30:953-965. http://dx.doi.org/10.1016/j.idc.2016.07.009.

Said HS, and Abdelmegeed ES. 2019. Emergence of multidrug resistance and extensive drug resistance among enterococcal clinical isolates in Egypt. Infect Drug Resist 12:1113-1125. 10.2147/IDR.S189341 
Shahi F, Hamidi H, Khoshnood S, Mehdipour G, Dezfouli A, and Sheikh A. 2020. Virulence determinants and biofilm formation in clinical isolates of $<i>$ Enterococcus $</ i>$ : A crosssectional study. J Acute Dis 9:27-32. 10.4103/2221-6189.276079

Sharifi Y, Hasani A, Ghotaslou R, Varshochi M, Hasani A, Aghazadeh M, and Milani M. 2012. Survey of virulence determinants among vVancomycin resistant Enterococcus faecalis and Enterococcus faecium isolated from clinical specimens of hospitalized patients of North west of Iran. Open Microbiol J 6:34-39. 10.2174/1874285801206010034

Smith JR, Barber KE, Raut A, Aboutaleb M, Sakoulas G, and Rybak MJ. 2015. Beta-Lactam combinations with daptomycin provide synergy against vancomycin-resistant Enterococcus faecalis and Enterococcus faecium. J Antimicrob Chemother 70:1738-1743. 10.1093/jac/dkv007

Ulu-Kilic A, Özhan E, Altun D, Perçin D, Güneş T, and Alp E. 2016. Is it worth screening for vancomycin-resistant Enterococcus faecium colonization?: Financial burden of screening in a developing country. Am J Infect Control 44:e45-49. 10.1016/j.ajic.2015.11.008

Vankerckhoven V, Van Autgaerden T, Vael C, Lammens C, Chapelle S, Rossi R, Jabes D, and Goossens H. 2004. Development of a multiplex PCR for the detection of asa1, gelE, cylA, esp, and hyl genes in enterococci and survey for virulence determinants among European hospital isolates of Enterococcus faecium. J Clin Microbiol 42:4473-4479.

Versalovic J, Koeuth T, and Lupski JR. 1991. Distribution of repetitive DNA sequences in eubacteria and application to fingerprinting of bacterial genomes. Nucleic Acids Res 19:6823-6831. 10.1093/nar/19.24.6823

Werner G, Coque TM, Hammerum AM, Hope R, Hryniewicz W, Johnson A, Klare I, Kristinsson KG, Leclercq R, Lester CH, Lillie M, Novais C, Olsson-Liljequist B, Peixe LV, Sadowy E, Simonsen GS, Top J, Vuopio-Varkila J, Willems RJ, Witte W, and Woodford N. 2008. Emergence and spread of vancomycin resistance among enterococci in Europe. Euro Surveill 13.

Yang JX, Li T, Ning YZ, Shao DH, Liu J, Wang SQ, and Liang GW. 2015. Molecular characterization of resistance, virulence and clonality in vancomycin-resistant Enterococcus faecium and Enterococcus faecalis: A hospital-based study in Beijing, China. Infect Genet Evol 33:253-260. 10.1016/j.meegid.2015.05.012 
486

487

488

489

490

491

492

493

494

495

Zaheer R, Cook SR, Barbieri R, Goji N, Cameron A, Petkau A, Polo RO, Tymensen L, Stamm C, Song J, Hannon S, Jones T, Church D, Booker CW, Amoako K, Van Domselaar G, Read RR, and McAllister TA. 2020. Surveillance of Enterococcus spp. reveals distinct species and antimicrobial resistance diversity across a One-Health continuum. Sci Rep 10:3937. 10.1038/s41598-020-61002-5

Zalipour M, Esfahani BN, and Havaei SA. 2019. Phenotypic and genotypic characterization of glycopeptide, aminoglycoside and macrolide resistance among clinical isolates of Enterococcus faecalis: a multicenter based study. BMC Res Notes 12:292. 10.1186/s13104-019-4339-4 
Figure 1

Multiplex PCR positive isolates.

Lane $M=$ marker 100-1000 bp; lane 1 = E. faecalis ATCC 51299 vanB positive control; lane 2 $=E$. faecium ATCC 700221 vanA positive control; lane $3=$ vanA positive from clinical strain E. faecium ; lane 4 = esp positive from clinical strain E. faecium; lane $5=$ hyl positive from clinical strain $E$. faecium; lane $6=$ rrs genes and $d d l_{E \text {. faecium }}$ from clinical strain; lane $7=$ negative control . 


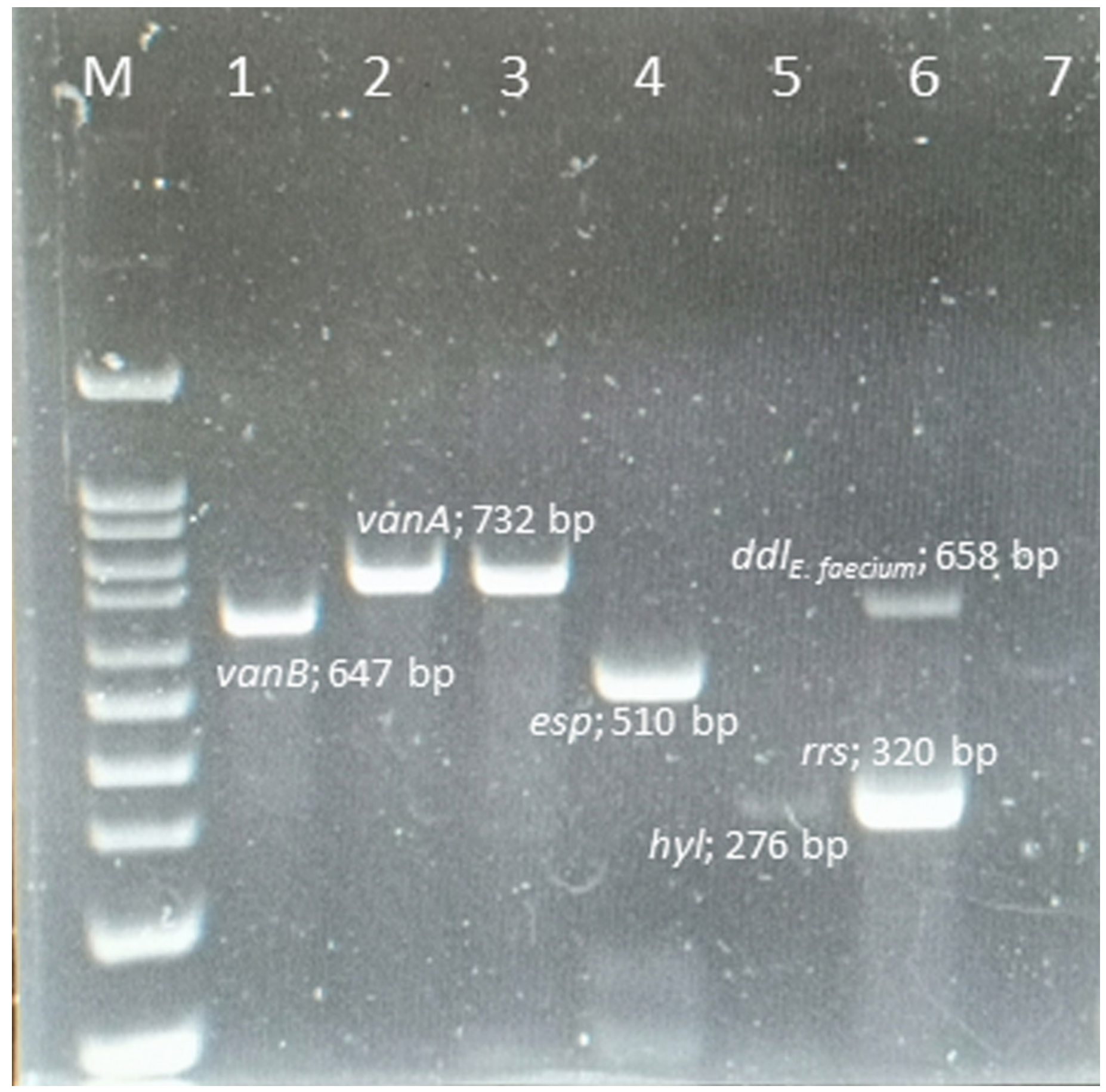


Figure 2

Dendrogram of ERIC-PCR patterns among 90 VRE isolates

Dendrogram of ERIC-PCR patterns showing the genetic relationship among 90 VRE isolates collected from clinical specimen in Songklanagarind Hospital, Thailand. Similarity $>95 \%$ were considered for clustering of isolates. 


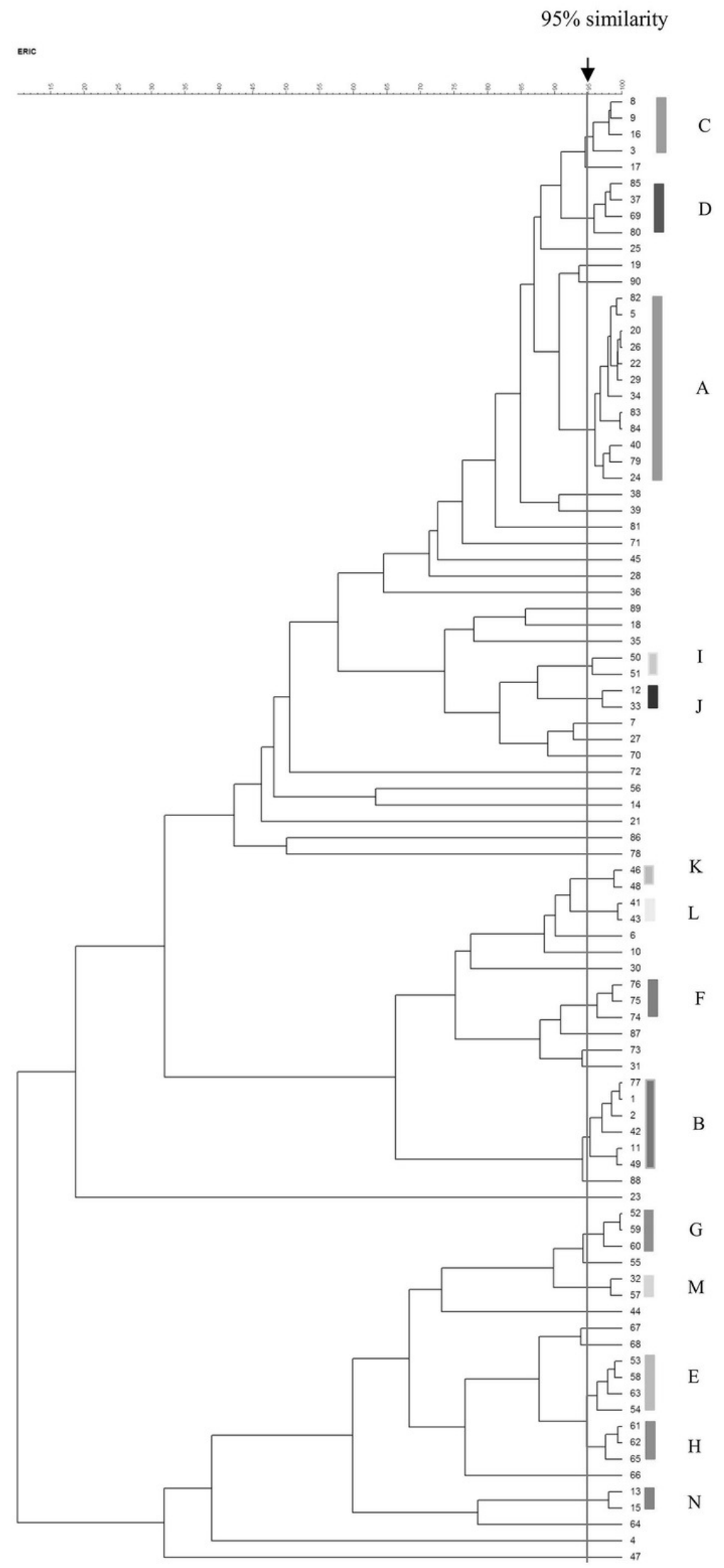




\section{Table $\mathbf{1}$ (on next page)}

Data on nosocomial infections due to Enterococci for 2011 to 2019 per year from a tertiary care, Songklanagarind Hospital. 
1 Data on nosocomial infections due to Enterococci for 2011 to 2019 per year from a tertiary

2 care, Songklanagarind Hospital.

3

\begin{tabular}{ccc}
\hline Year & $\begin{array}{c}\text { Total number }(\mathbf{N}) \text { of } \\
\text { nosocomial enterococcal } \\
\text { infections }\end{array}$ & $\begin{array}{c}\text { Number of VRE } \\
\text { infections, } \mathbf{n}(\%(\mathbf{n} / \mathbf{N}), \\
\text { proportion in\%) }\end{array}$ \\
\hline 2011 & 1196 & $5(6,0.4)$ \\
2012 & 1132 & $16(18,1.4)$ \\
2013 & 839 & $12(13,1.4)$ \\
2014 & 645 & $28(31,4.3)$ \\
2015 & 1252 & $5(6,0.4)$ \\
2016 & 1195 & $5(6,0.4)$ \\
2017 & 1325 & $3(3,0.2)$ \\
2018 & 810 & $8(9,1.0)$ \\
2019 & 879 & $8(9,0.9)$ \\
\hline Total & $\mathbf{9 2 7 3}$ & $\mathbf{9 0}(\mathbf{1 0 0}, \mathbf{1 0 . 5})$ \\
\hline
\end{tabular}

4

5 


\section{Table 2 (on next page)}

List of oligonucleotide primers used in the genetic profiling of resistance genes and virulence genes among the isolates in this study. 
1 List of oligonucleotide primers used in the genetic profiling of resistance genes and

2 virulence genes among the isolates in this study.

3

\begin{tabular}{|c|c|c|c|c|}
\hline Gene & Primer name & Oligonucleotide sequence ( $5^{\prime}$ to $\left.3^{\prime}\right)$ & $\begin{array}{l}\text { Product } \\
\text { size } \\
\text { (bp) }\end{array}$ & Reference \\
\hline E. faecalis & ddl_E. faecalis & ATCAAGTACAGTTAGTCT & 941 & $\begin{array}{l}\text { Dutka-Malen S et al } 1995 \\
\text { [16] }\end{array}$ \\
\hline & & ACGATTCAAAGCTAACTG & & \\
\hline E. faecium & ddl_E. faecium & $\begin{array}{l}\text { TTGAGGCAGACCAGATTGACG } \\
\text { TATGACAGCGACTCCGATTCC }\end{array}$ & 658 & \\
\hline rrs & $\begin{array}{l}\text { 16S rRNA_F } \\
16 S \text { rRNA_R }\end{array}$ & $\begin{array}{l}\text { GGATTAGATACCCTGGTAGTCC } \\
\text { TCGTTGCGGGACTTAACCCAAC }\end{array}$ & 320 & \\
\hline $\operatorname{van} A$ & $\operatorname{van} A+$ & GGGAAAACGACAATTGC & 732 & $\begin{array}{l}\text { Bhatt, Puneet et al } 2015 \\
\text { [7] }\end{array}$ \\
\hline $\operatorname{van} B$ & $\begin{array}{l}\text { vanA- } \\
\text { vanB+ } \\
\text { vanB- }\end{array}$ & $\begin{array}{l}\text { GTACAATGCGGCCGTTA } \\
\text { ACGGAATGGGAAGCCGA } \\
\text { TGCACCCGATTTCGTTC }\end{array}$ & 647 & \\
\hline $\operatorname{vanC}$ & $\begin{array}{l}\text { vanC+ } \\
\text { vanC- }\end{array}$ & $\begin{array}{l}\text { ATGGATTGGTAYTKGTAT } \\
\text { TAGCGGGAGTGMCYMGTAA }\end{array}$ & $815 / 827$ & \\
\hline $\operatorname{van} D$ & $\begin{array}{l}\text { vanD+ } \\
\operatorname{vanD}\end{array}$ & $\begin{array}{l}\text { TGTGGGATGCGATATTCAA } \\
\text { TGCAGCCAAGTATCCGGTAA }\end{array}$ & 500 & \\
\hline vanE & $\begin{array}{l}\text { vanE+ } \\
\text { vanE- }\end{array}$ & $\begin{array}{l}\text { TGTGGGATCGGAGCTGCAG } \\
\text { ATAGTTTAGCTGGTAAC }\end{array}$ & 430 & \\
\hline $\operatorname{van} G$ & $\begin{array}{l}\text { vanG+ } \\
\text { vanG- }\end{array}$ & $\begin{array}{l}\text { CGGCATCCGCTGTTTTTTGA } \\
\text { GAACGATAGACCAATGCCTT }\end{array}$ & 941 & \\
\hline asa & ASA 11 & GCACGCTATTACGAACTATGA & 373 & $\begin{array}{l}\text { Vankerckhoven V et al } \\
2004 \text { [19] }\end{array}$ \\
\hline & ASA 12 & TAAGAAAGAACATCACCACGA & & \\
\hline gel & $\begin{array}{l}\text { GEL } 11 \\
\text { GEL } 12\end{array}$ & $\begin{array}{l}\text { TATGACAATGCTTTTTGGGAT } \\
\text { AGATGCACCCGAAATAATATA }\end{array}$ & 213 & \\
\hline cyt & $\begin{array}{l}\text { CYT I } \\
\text { CYT IIb }\end{array}$ & $\begin{array}{l}\text { ACTCGGGGATTGATAGGC } \\
\text { GCTGCTAAAGCTGCGCTT }\end{array}$ & 688 & \\
\hline esp & $\begin{array}{l}\text { ESP } 14 \mathrm{~F} \\
\text { ESP } 12 R\end{array}$ & $\begin{array}{l}\text { AGATTTCATCTTTTGATTCTTGGG } \\
\text { AATTGATTCTTTAGCATCTGG }\end{array}$ & 510 & \\
\hline hyl & $\begin{array}{l}\text { HYL n1 } \\
\text { HYL n2 }\end{array}$ & $\begin{array}{l}\text { ACAGAAGAGCTGCAGGAAATG } \\
\text { GACTGACGTCCAAGTTTCCAA }\end{array}$ & 276 & \\
\hline$c p d$ & $\begin{array}{l}\mathrm{cpd}-\mathrm{F} \\
\mathrm{cpd}-\mathrm{R}\end{array}$ & $\begin{array}{l}\text { TGGTGGGTTATTTTTCAATTC } \\
\text { TACGGCTCTGGCTTACTA }\end{array}$ & 782 & Elsner H-A et al 2000 [20] \\
\hline$e b p$ & ebpA-F & AAAAATGATTCGGCTCCAGAA & 101 & $\begin{array}{l}\text { Bourgogne A et al } 2007 \\
\text { [18] }\end{array}$ \\
\hline & ebpA-R & TGCCAGATTCGCTCTCAAAG & & \\
\hline
\end{tabular}




\section{Table 3 (on next page)}

Demographic and clinical characteristics of patients with VRE at Songklanagarind Hospital between February 2011 and February 2019. 
1 Demographic and clinical characteristics of patients with VRE at Songklanagarind

2 Hospital between February 2011 and February 2019.

3

\begin{tabular}{|c|c|c|c|c|}
\hline Variables & $\begin{array}{l}\text { MDR-VRE } \\
n(\%)\end{array}$ & $\begin{array}{l}\text { XDR-VRE } \\
n(\%)\end{array}$ & Total (\%) & $P$ value \\
\hline Gender & & & & 0.883 \\
\hline Male & $26(40.6)$ & $11(42.3)$ & $37(41.1)$ & \\
\hline Female & $38(59.4)$ & $15(57.7)$ & $53(58.9)$ & \\
\hline Age in years & & & & 0.669 \\
\hline$\leq 12$ & $3(4.7)$ & 0 & $3(3.3)$ & \\
\hline $13-24$ & $4(7.8)$ & $2(7.7)$ & $6(6.7)$ & \\
\hline $25-64$ & $25(57.8)$ & $12(46.2)$ & $37(41.1)$ & \\
\hline$\geq 65$ & $32(60.9)$ & $12(46.2)$ & $44(48.9)$ & \\
\hline Source of samples & & & & $0.007^{*}$ \\
\hline Blood & $7(10.7)$ & $2(7.7)$ & $9(10.0)$ & \\
\hline Body fluid & $10(19.0)$ & $8(30.8)$ & $18(20.0)$ & \\
\hline Midstream urine & $6(10.7)$ & $3(11.5)$ & $9(10.0)$ & \\
\hline Pelvic & 0 & $1(3.8)$ & $1(1.1)$ & \\
\hline Pus & 0 & $1(3.8)$ & $1(1.1)$ & \\
\hline Rectal & $18(21.4)$ & 0 & $18(20.0)$ & \\
\hline Tissue & $3(7.1)$ & $5(19.2)$ & $8(8.9)$ & \\
\hline Urine & $20(29.8)$ & $6(23.1)$ & $26(28.9)$ & \\
\hline Hospital unit & & & & 0.353 \\
\hline Medical ward & $31(48.4)$ & $11(42.3)$ & $42(46.7)$ & \\
\hline Gynecology ward & $6(9.4)$ & $2(7.7)$ & $8(8.9)$ & \\
\hline Intensive care unit & $5(7.8)$ & $5(19.2)$ & $10(11.1)$ & \\
\hline Surgical ward & $15(23.4)$ & $3(11.5)$ & $18(20.0)$ & \\
\hline Operating room & $4(6.3)$ & $4(15.4)$ & $8(8.9)$ & \\
\hline Orthopedic ward & $1(1.6)$ & $1(3.8)$ & $2(2.2)$ & \\
\hline Pediatric ward & $2(3.1)$ & 0 & $2(2.2)$ & \\
\hline
\end{tabular}

4

5 MDR-VRE: multidrug-resistant vancomycin resistant enterococci; XDR-VRE: extensively drug-

6 resistant vancomycin resistant enterococci

$7 \quad{ }^{*} \mathrm{P}<0.05$ is significant. 
Table 4 (on next page)

List of antibiotics used in this study. 


\begin{tabular}{|c|c|c|c|c|c|}
\hline \multirow{2}{*}{ Mode of action } & \multirow{2}{*}{ Class } & \multirow{2}{*}{$\begin{array}{l}\text { No. of tested } \\
\text { isolates, } n(\%)\end{array}$} & \multicolumn{3}{|c|}{ Susceptibility testing results } \\
\hline & & & Sensitive & Intermediate & Resistant \\
\hline \multicolumn{6}{|l|}{ Cell membrane } \\
\hline Colistin & Lipopeptides & $8(8.9)$ & 4 & 0 & 4 \\
\hline \multicolumn{6}{|l|}{ Cell wall synthesis } \\
\hline Ampicillin & $\beta$-lactams (penicillins) & $67(74.4)$ & 0 & 0 & 67 \\
\hline Penicillin G & $\beta$-lactams (penicillins) & $17(18.9)$ & 0 & 0 & 17 \\
\hline Ertapenem & $\beta$-lactams (carbapenem) & $2(1.1)$ & 1 & 0 & 1 \\
\hline Imipenem & $\beta$-lactams (carbapenem) & $57(63.3)$ & 1 & 0 & 56 \\
\hline Meropenem & $\beta$-lactams (carbapenem) & $15(16.7)$ & 10 & 0 & 5 \\
\hline Cefoperazone & $\begin{array}{l}\beta \text {-lactams (cephalosporins), } 3^{\text {rd }} \\
\text { generation }\end{array}$ & $14(15.6)$ & 3 & 0 & 11 \\
\hline Cefotaxime & $\begin{array}{l}\beta \text {-lactams (cephalosporins), } 3^{\text {rd }} \\
\text { generation }\end{array}$ & $13(14.4)$ & 2 & 0 & 11 \\
\hline Ceftazidime & $\begin{array}{l}\beta \text {-lactams (cephalosporins), } 3^{\text {rd }} \\
\text { generation }\end{array}$ & $14(15.6)$ & 2 & 0 & 12 \\
\hline Ceftriaxone & $\begin{array}{l}\beta \text {-lactams (cephalosporins), } 3^{\text {rd }} \\
\text { generation }\end{array}$ & $12(13.3)$ & 2 & 0 & 10 \\
\hline Tazocin & $\begin{array}{l}\text { Combinations: piperacillin ( } \beta \text { - } \\
\text { lactams) and tazobactam ( } \beta \text { - } \\
\text { lactamase inhibitors) }\end{array}$ & $12(13.3)$ & 0 & 0 & 12 \\
\hline Vancomycin & Glycopeptides & $20(22.2)$ & 0 & 0 & 20 \\
\hline \multicolumn{6}{|l|}{ DNA gyrase } \\
\hline Ciprofloxacin & Fluoroquinolone & $2(2.2)$ & 0 & 0 & 2 \\
\hline Norfloxacin & Fluoroquinolone & $5(5.6)$ & 0 & 0 & 5 \\
\hline
\end{tabular}




\begin{tabular}{|c|c|c|c|c|c|}
\hline \multirow{2}{*}{ Mode of action } & \multirow{2}{*}{ Class } & \multirow{2}{*}{$\begin{array}{l}\text { No. of tested } \\
\text { isolates, } n(\%)\end{array}$} & \multicolumn{3}{|c|}{ Susceptibility testing results } \\
\hline & & & Sensitive & Intermediate & Resistant \\
\hline \multicolumn{6}{|c|}{ (30S ribosomal subunit) } \\
\hline Gentamicin & Aminoglycosides & $21(23.3)$ & 7 & 1 & 13 \\
\hline
\end{tabular}


Table 5 (on next page)

Vancomycin MIC results among 90 VRE isolates. 
1 Vancomycin MIC results among 90 VRE isolates.

2

\begin{tabular}{ccc}
\hline vancomycin $(\mu \mathrm{g} / \mathrm{ml})$ & No. of infection & Percent of infection $(\%)$ \\
\hline 0.75 & 2 & 2.2 \\
4 & 2 & 2.2 \\
16 & 1 & 1.1 \\
24 & 0 & 0 \\
32 & 0 & 0 \\
48 & 1 & 1.1 \\
64 & 3 & 3.3 \\
96 & 1 & 1.1 \\
128 & 7 & 7.8 \\
256 & 53 & 58.9 \\
$>256$ & 20 & 22.2 \\
\hline Total & 90 & 100
\end{tabular}

3

4 


\section{Table 6(on next page)}

ERIC-PCR pattern, source, hospital collection location, antibiogram profile, and isolation date of multidrug-resistant (MDR) and extensively drug-resistant (XDR)-VRE strains from hospitalized patients at Songklanagarind Hospital, southern Thailand. 
1 ERIC-PCR pattern, source, hospital collection location, antibiogram profile, and isolation

\section{2 date of multidrug-resistant (MDR) and extensively drug-resistant (XDR)-VRE strains from}

3 hospitalized patients at Songklanagarind Hospital, southern Thailand.

\begin{tabular}{|c|c|c|c|c|c|c|c|c|c|}
\hline $\begin{array}{l}\text { code of } \\
\text { isolates }\end{array}$ & ID & source & ward & $\begin{array}{c}\text { Male } \\
(\mathrm{M}) \\
\text { Female } \\
(\mathrm{F})\end{array}$ & age & $\begin{array}{l}\text { Collection date } \\
\text { (day/month/year) }\end{array}$ & $\begin{array}{l}\text { Resistance } \\
\text { genes }\end{array}$ & $\begin{array}{c}\text { Resistance } \\
\text { patterns }\end{array}$ & $\begin{array}{l}\text { ERIC } \\
\text { types }\end{array}$ \\
\hline 5 & 874-3-PSU & rectal & surgical ward & $\mathrm{M}$ & 70 & 05032014 & vanA, esp & MDR & A \\
\hline 20 & 1949-PSU & rectal & medical ward & $M$ & 60 & 28072011 & $\operatorname{vanA}$, esp & MDR & A \\
\hline 22 & 1114-PSU & blood & surgical ward & $\mathrm{F}$ & 64 & 07082014 & $\operatorname{van} A$, esp & MDR & A \\
\hline 24 & 198-PSU & $\begin{array}{l}\text { body } \\
\text { fluid }\end{array}$ & surgical ward & $\mathrm{M}$ & 67 & 02082014 & vanA, esp & MDR & A \\
\hline 26 & 1949-PSU & rectal & medical ward & $M$ & 60 & 13082014 & $\operatorname{van} A, e s p$ & MDR & $\mathrm{A}$ \\
\hline 29 & 1007-PSU & rectal & medical ward & $M$ & 87 & 06082014 & $\operatorname{van} A, e s p$ & MDR & A \\
\hline 34 & 4129-PSU & tissue & $\begin{array}{l}\text { intensive care } \\
\text { units }\end{array}$ & $\mathrm{F}$ & 53 & 28022012 & $\operatorname{van} A, \operatorname{esp}$ & XDR & A \\
\hline 40 & 5056-PSU & urine & medical ward & $F$ & 88 & 29032012 & vanA, esp & XDR & A \\
\hline 79 & 5296-12br-PSU & $\begin{array}{l}\text { body } \\
\text { fluid }\end{array}$ & medical ward & $\mathrm{M}$ & 73 & 24122018 & vanA, esp & MDR & $\bar{A}$ \\
\hline 82 & 2484-1u-PSU & urine & medical ward & $\mathrm{F}$ & 74 & 11012019 & $\operatorname{van} A$, esp & MDR & A \\
\hline 83 & 7028-10u-PSU & urine & surgical ward & $\mathrm{M}$ & 70 & 30102018 & $\operatorname{van} A, e s p$ & MDR & $\mathrm{A}$ \\
\hline 84 & 2079-4u-PSU & urine & medical ward & $\mathrm{F}$ & 44 & 11042018 & $\operatorname{vanA}, e s p$ & MDR & A \\
\hline 1 & 3044-PSU & rectal & medical ward & $\mathrm{M}$ & 73 & 17032014 & $\operatorname{van} A$, esp & MDR & $\mathrm{B}$ \\
\hline 2 & 3576-PSU & rectal & surgical ward & $\mathrm{M}$ & 90 & 20032014 & $\operatorname{van} A$, esp & MDR & $\mathrm{B}$ \\
\hline 11 & 3180-8-PSU & urine & medical ward & $\mathrm{F}$ & 38 & 19082015 & $\operatorname{vanA}, e s p$ & MDR & $\mathrm{B}$ \\
\hline 42 & 696ii-PSU & blood & medical ward & $\mathrm{F}$ & 63 & 04122013 & $\operatorname{van} A$, esp & MDR & $\mathrm{B}$ \\
\hline 49 & 580-PSU & $\begin{array}{l}\text { body } \\
\text { fluid }\end{array}$ & $\begin{array}{l}\text { intensive care } \\
\text { units }\end{array}$ & $\mathrm{F}$ & 21 & 04022013 & vanA, hyl & XDR & B \\
\hline 77 & 5296-PSU & $\begin{array}{l}\text { body } \\
\text { fluid }\end{array}$ & medical ward & $\mathrm{M}$ & 73 & 24122018 & $\operatorname{van} A, e s p$ & MDR & $B$ \\
\hline 3 & 3374II-PSU & blood & medical ward & $\mathrm{F}$ & 23 & 20022014 & vanA, esp & MDR & C \\
\hline 8 & 3384-PSU & rectal & surgical ward & $\mathrm{F}$ & 71 & 19032014 & $\operatorname{vanA}$, esp & MDR & $\mathrm{C}$ \\
\hline 9 & 3576-PSU & rectal & surgical ward & $\mathrm{F}$ & 90 & 20032014 & $\operatorname{vanA}$, esp & MDR & C \\
\hline 16 & 2725-PSU & tissue & medical ward & $M$ & 67 & 15032016 & $\operatorname{vanA}$, esp & XDR & C \\
\hline 37 & 1879-PSU & blood & medical ward & $M$ & 86 & 10032011 & $\operatorname{vanA}$, esp & XDR & $\mathrm{D}$ \\
\hline 69 & 874-PSU & rectal & surgical ward & $\mathrm{M}$ & 70 & 05032014 & vanA, esp & MDR & $\mathrm{D}$ \\
\hline 80 & 940-1u-PSU & urine & medical ward & $\mathrm{F}$ & 85 & 04012019 & $\operatorname{vanA}$, esp & MDR & D \\
\hline 85 & $5005-12 u$ & urine & medical ward & $\mathrm{F}$ & 83 & 23122018 & $\operatorname{vanA}$, esp & MDR & $\mathrm{D}$ \\
\hline 53 & 762-PSU & $\begin{array}{l}\text { body } \\
\text { fluid }\end{array}$ & medical ward & $\mathrm{M}$ & 37 & 05022014 & $\operatorname{van} A, e s p$ & XDR & $E$ \\
\hline 54 & 176-PSU & blood & $\begin{array}{l}\text { gynecology } \\
\text { ward }\end{array}$ & $\mathrm{F}$ & 25 & 01112013 & $\operatorname{van} A$ & MDR & $E$ \\
\hline 58 & 1243-PSU & MSU & $\begin{array}{l}\text { gynecology } \\
\text { ward }\end{array}$ & $\mathrm{F}$ & 70 & 08052013 & $\operatorname{vanA}, e s p$ & XDR & $E$ \\
\hline 63 & 135-PSU & $\begin{array}{l}\text { body } \\
\text { fluid }\end{array}$ & operating room & $\mathrm{F}$ & 64 & 01052012 & $\operatorname{van} A$ & XDR & $E$ \\
\hline 74 & 3784-PSU & rectal & medical ward & $M$ & 46 & 21032014 & $\operatorname{van} A$, esp & MDR & $\mathrm{F}$ \\
\hline 75 & 32-PSU & urine & medical ward & $\mathrm{F}$ & 79 & 01062012 & $\operatorname{van} A$, esp & XDR & $\mathrm{F}$ \\
\hline 76 & 5552-1 I-PSU & blood & $\begin{array}{l}\text { intensive care } \\
\text { units }\end{array}$ & $\mathrm{F}$ & 0.25 & 24012019 & $\operatorname{vanA}, e s p$ & MDR & $\mathrm{F}$ \\
\hline 52 & 1134-PSU & rectal & $\begin{array}{l}\text { gynecology } \\
\text { ward }\end{array}$ & $\mathrm{F}$ & 52 & 07112013 & $\operatorname{vanA}$, esp & MDR & G \\
\hline 59 & 3236-PSU & MSU & medical ward & $\mathrm{F}$ & 50 & 18102016 & $\operatorname{vanA}$, esp & XDR & $\mathrm{G}$ \\
\hline 60 & 977-PSU & MSU & medical ward & $\mathrm{F}$ & 90 & 6102016 & $\operatorname{vanA}$, hyl & XDR & G \\
\hline 61 & 1630-PSU & $\begin{array}{l}\text { body } \\
\text { fluid }\end{array}$ & medical ward & $\mathrm{F}$ & 74 & 10092013 & $\operatorname{vanA}$, esp & MDR & $\mathrm{H}$ \\
\hline 62 & 4399-PSU & urine & surgical ward & $\mathrm{F}$ & 28 & 29042012 & vanA, esp & XDR & $\mathrm{H}$ \\
\hline 65 & 3093-PSU & rectal & $\begin{array}{l}\text { gynecology } \\
\text { ward }\end{array}$ & $\mathrm{F}$ & 52 & 18112013 & $\operatorname{van} A, \operatorname{esp}$ & MDR & $\mathrm{H}$ \\
\hline 50 & 4215-PSU & urine & medical ward & $\mathrm{F}$ & 68 & 22042012 & $\operatorname{van} A, e s p$ & MDR & 1 \\
\hline
\end{tabular}




\begin{tabular}{|c|c|c|c|c|c|c|c|c|c|}
\hline $\begin{array}{l}\text { code of } \\
\text { isolates }\end{array}$ & ID & source & ward & $\begin{array}{c}\text { Male } \\
(\mathrm{M}) \\
\text { Female } \\
(\mathrm{F})\end{array}$ & age & $\begin{array}{l}\text { Collection date } \\
\text { (day/month/year) }\end{array}$ & $\begin{array}{l}\text { Resistance } \\
\text { genes }\end{array}$ & $\begin{array}{c}\text { Resistance } \\
\text { patterns }\end{array}$ & $\begin{array}{l}\text { ERIC } \\
\text { types }\end{array}$ \\
\hline 51 & 5324-PSU & $\begin{array}{l}\text { body } \\
\text { fluid }\end{array}$ & surgical ward & $\mathrm{M}$ & 66 & 30082012 & vanA, esp & XDR & I \\
\hline 12 & 3672-PSU & urine & surgical ward & $F$ & 79 & 20022015 & vanA, esp & MDR & $\mathrm{J}$ \\
\hline 33 & 1329-PSU & rectal & medical ward & $M$ & 74 & 08082014 & vanA, esp & MDR & $\mathrm{J}$ \\
\hline 46 & 4006-PSU & urine & medical ward & $\mathrm{F}$ & 73 & 24122013 & vanA & MDR & $\mathrm{K}$ \\
\hline 48 & 3209-PSU & $\begin{array}{l}\text { body } \\
\text { fluid }\end{array}$ & medical ward & $M$ & 66 & 19082012 & vanA, esp & XDR & $\mathrm{K}$ \\
\hline 41 & 910-PSU & MSU & medical ward & $\mathrm{F}$ & 85 & 06082012 & vanA, esp & MDR & L \\
\hline 43 & 2000-PSU & MSU & $\begin{array}{l}\text { gynecology } \\
\text { ward }\end{array}$ & $\mathrm{F}$ & 42 & 11112013 & $\operatorname{van} A$ & MDR & L \\
\hline 32 & 198-PSU & $\begin{array}{l}\text { body } \\
\text { fluid }\end{array}$ & surgical ward & $\mathrm{M}$ & 63 & 02082014 & vanA, esp & MDR & $\mathrm{M}$ \\
\hline 57 & 5245-PSU & pelvic & operating room & $\mathrm{F}$ & 19 & 28092016 & $\operatorname{van} A, e s p$ & XDR & $\mathrm{M}$ \\
\hline 13 & 3398-PSU & urine & surgical ward & $\mathrm{M}$ & 78 & 18092015 & $\operatorname{vanA}$, esp & MDR & $\mathrm{N}$ \\
\hline 15 & 4190-PSU & tissue & medical ward & $F$ & 38 & 25042017 & vanA, esp & MDR & $\mathrm{N}$ \\
\hline
\end{tabular}

4

5 MSU: mid-stream urine

6 BioSample accessions: SAMN18201951, SAMN18201952, SAMN18201953,

7 SAMN18201954, SAMN18201955, SAMN18201956, SAMN18201957, SAMN18201958,

8 SAMN18201959, SAMN18201960 ...

9 Temporary SubmissionID: SUB9086272

10 